УДК 658.64

\title{
СУЧАСНІ НАПРЯМКИ РОЗВИТКУ КУРОРТНОГО ГОТЕЛЮ
}

\section{MODERN DIRECTIONS OF DEVELOPMENT OF RESORT HOTEL}

\author{
Кирпіченкова Оксана Миколаївна \\ кандидат технічних наук, \\ Національний університет харчових технологій \\ ORCID: https://orcid.org/0000-0003-0215-5316 \\ Ущаповський Артем Олегович \\ асистент, \\ Національний університет харчових технологій \\ ORCID: https://orcid.org/0000-0001-7853-5070 \\ Боброва Ярослава Олегівна \\ магістрант, \\ Національний університет харчових технологій \\ ORCID: https://orcid.org/0000-0002-0269-3598
}

\section{Kyrpichenkova Oksana, Ushchapovsky Artem, Bobrova Yaroslava \\ National University of Food Technologies}

\begin{abstract}
В даній статті пропонуються сучасні рішення для курортного готелю в місті Приморськ Запорізької області, які пов'язані з морськими екскурсіями та інноваційним підходом до кейтерингу. Вітчизняні готелі залучають нових гостей нестандартними послугами, зручностями, доброзичливою атмосферою, відпочинком, обстановкою, романтикою, емоціями, адреналіном. Запропоновано ряд морських екскурсій різної тривалості, що будуть супроводжуватися кейтерингом. Кейтеринг нині $€$ одним із найбільш динамічних секторів ресторанного бізнесу в Україні. Крім того, важливе значення має не лише постачання їжі, а й організація відповідних масових заходів. Окрім прослуховування екскурсій на суднах, гостей також залучатимуть в процес створення страв - найбільш затребуваний сьогодні прийом.
\end{abstract}

Ключові слова: готель, кейтеринг, морський туризм, нестандартні послуги, сервіс.

В данной статье предлагаются современные решения для курортного отеля в городе Приморск Запорожской области, связанные с морскими экскурсиями и инновационным подходом к кейтерингу. Отечественные отели привлекают новых гостей нестандартными услугами, удобствами, доброжелательной атмоссрерой, отдыхом, обстановкой, романтикой, эмоциями, адреналином. Предложен ряд морских экскурсий различной продолжительности, которые будут сопровождаться кейтерингом. Кейтеринг настоящее время является одним из самых динамичных секторов ресторанного бизнеса в Украине. Кроме того, важное значение имеет не только поставки пищи, но и организация соответствующих массовых мероприятий. Кроме прослушивания экскурсий на судах, гостей также будут привлекать к процессу создания блюд - наиболее востребованный сегодня прием.

Ключевые слова: гостиница, кейтеринг, морской туризм, нестандартные услуги, сервис.

This article offers modern solutions for a resort hotel in the city of Primorsk, Zaporozhye region, which are associated with sea excursions and a modern approach to catering. Domestic hotels attract new guests with non-standard services, amenities, friendly atmosphere, recreation, atmosphere, romance, emotions, adrenaline. A number of sea excursions of different duration are offered, which will be accompanied by catering. Catering is currently one of the most dynamic sectors of the restaurant business in Ukraine, where there is high competition. For the organization of catering services on ships, it is necessary to provide equipment that will fully meet the requirements of mobility, will provide high consumer performance of restaurant products. One of the ways to serve food in an original way can be the use of non-standard utensils. For example, you can use glass jars or glasses for soup, and deep plates for desserts or snacks. A feature of catering at the hotel will be the ability to implement a themed menu on request. In addition, it is important not only to supply food, but also to organize appropriate mass events. In addition to listening 
to excursions on ships, it is also advisable to involve guests in the process of creating or preparing meals - the most relevant method of entertaining guests today. Water tourism in the city of Primorsk can be represented by travel on sea waves. Transport in this case can be a yacht, a pleasure boat, and a speedboat. The most interesting and original walks from the point of view of some tourists are kayaking. But this type of recreation is suitable for physically fit tourists. Most prefer a more fashionable vacation on relatively large ships: a motor boat, a pleasure yacht. Active recreation at sea is much more interesting than a traditional lazy vacation on the beach. These are completely new sensations and emotions, an interesting look at the usual landscapes of the coast, a great way to unite a team of friends, colleagues or family members. Therefore, resort hotels should expand the list of additional features in order to have an advantage over competitors and attract more customers.

Keywords: hotel, catering, sea tourism, non-standard services, service.

Постановка проблеми. Запорізька область має три курортних напрямки - Бердянськ, Кирилівка та Приморськ. Тамтешні готельєри та керівники баз відпочинку зазвичай відкривають сезон на травневі свята. Проте в 2020 році через коронавірус керівництво області посилило протиепідемічні заходи та закрило в"їзд на море, встановивши додаткові карантинні пости.

За даними опитування у 2019 році 45\% респондентів відповіли, що виїжджають на відпочинок принаймні раз на рік, третина 3 них - за кордон [1]. Зараз через закриті кордони і відсутність авіасполучення з більшістю популярних туристичних країн внутрішній туризм в Україні отримав відчутний поштовх до розвитку.

Потенційні туристи вимагають належного сервісу та згодні віддавати за нього більші гроші, так звані vір-тури сьогодні, користуються високим попитом, із-за вимушеного закриття кордонів.

На сьогоднішній день для просування свого готелю керівництво повинно подумати над тим, що дасть перевагу їх закладу при порівнянні $з$ іншими. Для курортного готелю це може бути організація морських подорожей, екскурсій з організацією кейтерингу.

Перевезення людей по воді відносяться до найбільш стародавніх видів подорожей 3 використанням транспортних засобів. Спочатку це були дерев'яні плоти і човни, які в сучасному туризмі скоріше можна віднести до нетрадиційних видів транспорту [2].

Морський туризм має достатньо тривалу передісторію. Перші круїзні послуги як основний вид послуг морського туризму мали елітний характер і низький рівень безпеки. Морський бізнес почав активно розвиватися 3 1860 по 1960 рр. У сучасних умовах морський бізнес щорічно нарощує темпи розвитку. Понад 150 крупних судновласників американського, грецького, італійського, датського, норвезького походження пропонують широкий асортимент морських послуг, удоскона- люючи їх якість, надаючи різноманітні додаткові послуги тощо.

Аналіз останніх досліджень і публікацій. Способи залучення клієнтів у готель, підвищення їх задоволеності від наданого сервісу і комплексу послуг, і, відповідно, збільшення доходів готелю - найактуальніша тема публікацій у готельно-ресторанній галузі. Звісно, велике значення має чистота в номері, комфрортні умови, доброзичливий, компетентний персонал, але клієнт передусім бажає отримати нові враження, в тому числі гастрономічні. $€$ думка, що для того, щоб готель був популярним серед гостей, йому необхідно мати в складі своїх послуг такі, які забезпечать йому конкурентні переваги. Сорера таких послуг необмежена і залежить від багатьох чинників.

Зокрема серед додаткових послуг слід виділити ті, що задовольняють особливі потреби гостей, зокрема можливість поряд 3 комфортним відпочинком отримати послуги, що стосуються корекції фрігури. Тож можливо запропонувати комплекс послуг для досягнення максимального результату при схудненні і моделюванні фрігури, який передбачає застосування інноваційної неінвазивної методики «кріоліполіз» та дотримання спеціальної дієти [3].

У світі досить велика кількість готелів, які $€$ цікавими та комфрортним для тих, хто бажає провести в них свій відпочинок. Але готелів, які пропонують окрім комфортного розміщення туристів, ще й можливість активного відпочинку для всіх бажаючих, в тому числі для осіб з обмеженими можливостями, досить невелика, хоча популярність їх висока. Створення в готелі центру активного відпочинку для осіб з обмеженими можливостями буде для них одним зі способів «розірвати» замкнутий простір, увійти в соціум, знайти нових друзів, отримати можливість для спілкування, пізнання світу [4].

Матеріал публікації [5] розкриває основні тенденції розвитку агротуризму в Україні та інноваційні для вітчизняної практики види 
туристичних занять. Досліджено і проаналізовано закордонний досвід агротуристичної діяльності, інноваційні напрямки розвитку агротуризму в Україні, наведена доцільність впровадження нових видів агророзваг з огляду на економічну ефективність та існуючий природничо-ресурсний потенціал України.

Науковцями досліджено можливість використання камери сенсорної депривації в готелях [6]. Встановлено можливість впровадження фрлоат-терапії санітарно-курортними комплексами України, задля розширення лікувальнооздоровчих послуг в закладах гостинності.

В роботі [7] розглянуто напрямки удосконалення роботи культурно-дозвілевої служби готельних підприємств, шляхом розширення анімаційних послуг. Досліджено світовий досвід в організації культурно-розважальних програм та їх ефрективність для розвитку туризму. Визначено, що перспективним напрямком для розширення анімаційного сервісу готельних підприємств є організація розважальних, ігрових та лікувально-оздоровчих заходів для дітей та підлітків різної вікової категорії.

Формулювання цілей статті. Одним 3 методів популяризації конкретного засобу розміщення $€$ надання нестандартних послуг. Конкретний підхід до організації розваг туристів, що відпочивають на морському узбережжі, створення програм екскурсій, що будуть супроводжуватися продуманим кейтерингом $€$ важливою складовою успіху готелю, буде сприяти підвищенню популярності готелю, фрормуванню лояльності клієнтів.

Виклад основного матеріалу дослідження. Основною метою морського туризму вважається забезпечення відпочинку і рекреації. Відповідно до цього морський туризм пов'язаний з використанням ресурсів моря і прибережних територій.

Морський туризм - це бізнес, що здійснюється в межах акваторії моря і прибережних територій 3 метою виробництва туристично-рекреаційних послуг для одержання прибутку [2].

Відповідно до цього визначення основними видами морського туризму $є$ круїзний, яхтовий та пляжний туризм. Також до переліку видів морського туризму входять дайвінг, рибалка, підводне полювання, віндсерфінг, сердрінг.

Останнім часом намітилася стійка тенденція переміщення послуг з організації споживання продукції та обслуговування споживачів із залів закладів ресторанного господарства до робочих місць (офріси, установи), місць відпочинку, місць святкування ювілеїв та інших офріційних та неофріційних святкових подій. Ця послуга має назву у міжнародній індустрії гостинності «catering» [8].

Слово «кейтеринг» походить від англійського дієслова «cater», що в перекладі означає «поставляти провізію», «обслуговувати споживачів», та словосполучень «рublice catering» - ресторанне господарство, а також «catering trade» - ресторанний бізнес. Так, на думку П'ятницької Н., суть кейтерингового обслуговування полягає в тому, що ресторан за спеціальними замовленнями (кейтерингова компанія) забезпечує замовнику приготування і доставку готової продукції ресторанного господарства у зазначене місце (додому, в осріс, на робоче місце, в місце відпочинку тощо), а також ресторанне обслуговування святкового заходу з наданням різних сервісних послуг.

Кейтеринг поза приміщенням, відноситься до найдинамічніших видів ресторанного обслуговування, передбачає, що у підприємства $€$ окремі пункти з приготування харчових продуктів, звідки приготовлена їжа доставляється в місце, яке визначає клієнт.

Існують чотири групи споживачів кейтерингового обслуговування:

- До першої групи належать корпоративні замовники - компанії, які проводять презентації, конфреренції з наступним фруршетом, а також корпоративні свята і вечірки. Кейтерингове обслуговування $\epsilon$ альтернативою організації заходу в ресторані, якщо подібна акція має масштабний характер і проведення ії є проблематичним через недостатню кількість місць.

- Друга група замовників - громадські організації, які проводять семінари, конореренції, благодійні заходи тощо.

- Третя група - приватні особи, які влаштовують сімейні свята (дні народження, весілля, ювілеї та ін.) у себе вдома або в іншому місці.

- Четверта група - певні колективи, які вважають за необхідне організовувати для своїх працівників комплексні обіди (сніданки, вечері).

Якщо ще недавно в Україні про кейтеринг було відоме тільки вузькому колу профресіоналів, то в даний час український ринок кейтерингу сорормований і широко розвинений. У цій ссрері існує безліч напрямків, видів обслуговування, а також різних ніш діяльності кейтеринг-служб, які мають свою конкретну специфріку.

Сьогодні кейтерингові послуги надають як окремі компанії, так і ресторани. Різниця в тому, що для самостійних структур - це 
основний вид бізнесу, а для закладів ресторанного господарства - додатковий заробіток. Якість роботи підприємства визначають грамотний персонал, правильно розроблене меню, наявність необхідного устаткування та інвентарю, уміння створити атмосореру.

Сьогодні український ринок кейтерингпослуг хаотичний і сповнений протиріч. 3 одного боку, існує багато ресторанів і кафре, які простоюють у ранкові та денні години (або в певні сезони) і не мають при цьому ані можливостей (автопарк, реклама, фрахівці), ані бажання організовувати власну службу кейтерингу.

В курортному готелі, де надаватимуться послуги морських екскурсій та кейтерингу для організації екскурсій, може бути такий орен- дований фрлот [9], табл. 1. Усі судна мають сучасне навігаційне оснащення, укомплектовані рятувальним обладнанням і засобами пожежогасіння. На будь-якому судні можна організувати азартну морську риболовлю. Для цього на яхтах $€$ рибопошукові ехолоти та рибальські снасті. Морський транспорт буде призначений як для здійснення екскурсійних морських прогулянок околицями, так і для тривалих плавань. Клас судів, наявність дозвільної документації та кваліфікація екіпажів гарантують безпеку і високий рівень комсрорту кожного подорожуючого.

Клас судів, наявність дозвільної документації та кваліфікація екіпажів гарантують безпеку і високий рівень комсрорту кожного подорожуючого.

\section{Флот готелю}

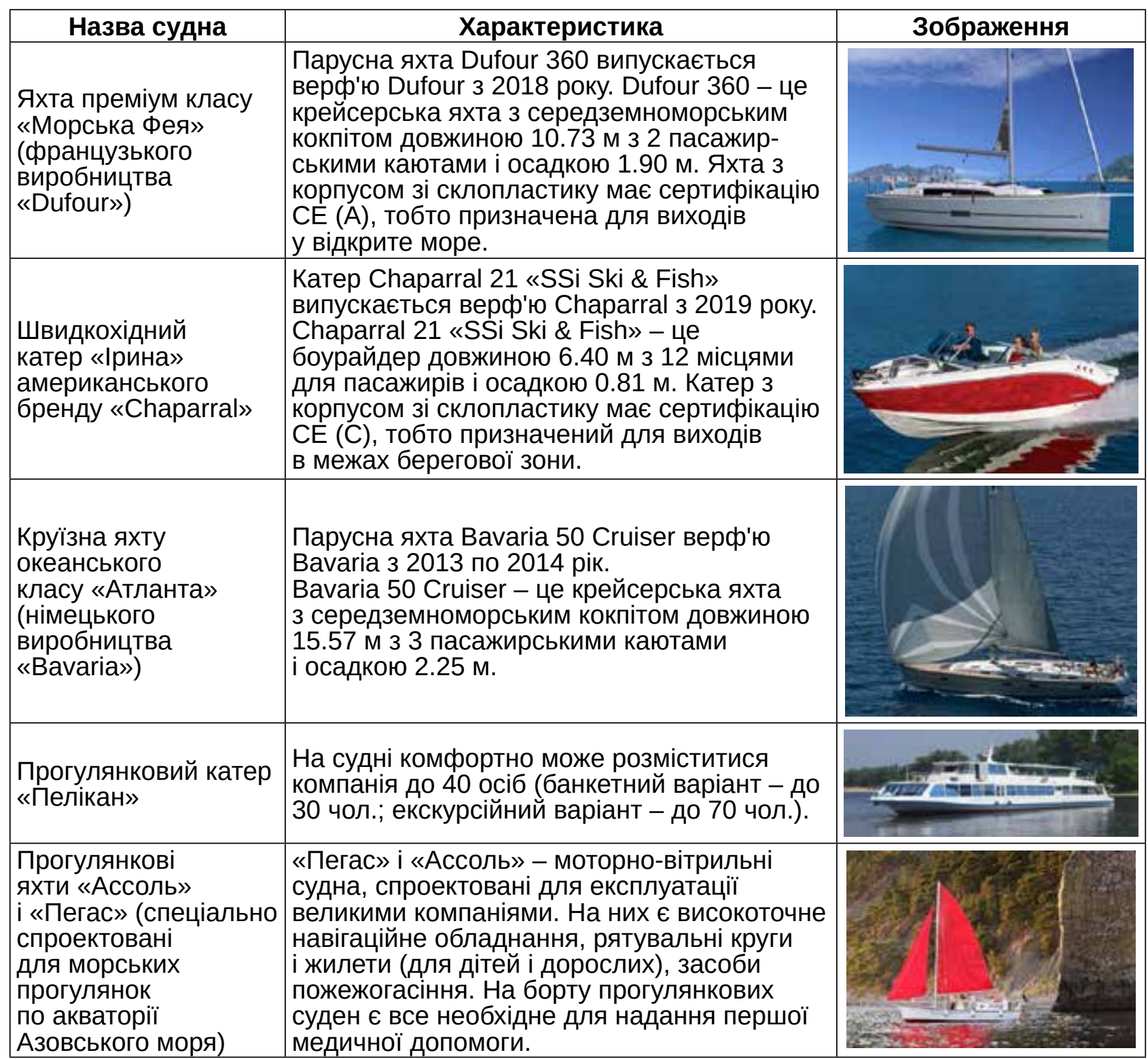


До уваги туристів пропонується:

- Індивідуальні програми для проведення особистого свята (весілля, ювілею), корпоративного заходу, зустрічі 3 друзями (парубочого, дівич-вечора), тематичної фротосесії, кейтерингове обслуговування.

- Влаштування морської рибалки. Морська прогулянка в складі загальної групи з виходом і купанням у відкритому морі.

- Організація захоплюючого морського круїзу. Туристи зможуть відвідати Батумі, Стамбул.

- Проведення ексклюзивної оглядової екскурсії в нічний час з романтичною вечерею.

3 кожним разом кількість екскурсій доповнюватиметься та розширюватиметься. На всіх заходах потрібно організувати послуги харчування.

Кейтеринг, або виїзне ресторанне обслуговування, нині $€$ одним із найбільш динамічних секторів ресторанного бізнесу в Україні. Вітчизняні ресторани торгують не лише їжею, вони торгують послугами, зручностями, доброзичливою атмосферою, відпочинком, романтикою, мріями, адреналіном. Крім того, важливе значення має не лише постачання їжі, а й організація відповідних масових заходів. На Заході склалася культура кейтерингу. Люди знають, яким має бути хороше свято, і довіряють фрахівцям. В Україні споживачі не мають уявлення про те, що таке хороша вечірка, але при цьому не завжди довіряють фрахівцям.

Для організації кейтерингового обслуговування на суднах має бути передбачено устаткування, яке повністю відповідатиме вимогам мобільності, забезпечуватиме високі споживчі показники продукції ресторанного господарства.
Одним із способів оригінальної подачі страви $€$ використання нестандартного посуду. Наприклад, в глибокій тарілці подаватимуться десерти або гарячі закуски, а для супу використовуватимуться скляні банки або келихи. Замість звичної порцеляни використовуватимуться вироби 3 каменю, дерева або інших матеріалів; закуски виноситимуться не на тарілках, а на підставках 3 дерева, в оригінальних світокубах і скляних конструкціях. В якості підставки для напоїв використовуватимуться фрігурні крижані скульптури в стилістиці заходи.

Окрім прослуховування екскурсій на суднах, гостей також залучатимуть в процес створення чи доготовлення страв - найбільш затребуваний сьогодні прийом. Організатори пропонуватимуть учасникам заходу необхідний набір продуктів, а далі вони готуватимуть все самостійно під наглядом шефр-кухаря.

- Гастрономічна анімація - протилежний варіант: кухар готує страву і демонструє свою майстерність гостям. В репертуарі кухарів приготування спагетті 3 томатів 3 «землею» 3 маслин і тертим сиром.

- Формат кулінарного поєдинку дуже популярний і ідеально підходить для корпоративних заходів, так як $є$ одночасно розважальним і командоутворюючим.

- Оригінальне поєднання інгредієнтів лосось і желе з ківі, вафрлі як булочки для бургера і так далі - ще одна можливість здивувати гостей.

- Експеримент із зовнішнім виглядом персоналу теж зробить захід особливим. Поле

Таблиця 2

Приклад морських екскурсій, що організовуватимуться готелем

\begin{tabular}{|c|c|c|}
\hline Екскурсії & День тижня & Характеристика \\
\hline $\begin{array}{l}\text { Оглядова } \\
\text { екскурсія }\end{array}$ & щоденно & $\begin{array}{l}\text { Тривалість екскурсії } 2 \text { години. Можливість дізнатися не тільки } \\
\text { історію міста Приморськ а і в цілому про Запоріжжя, побувати у } \\
\text { всіх курортних зонах. Дізнатися, де знаходяться кращі ринки зі } \\
\text { свіжими фруктами і морепродуктами за низькими цінами, кращі } \\
\text { масажні салони, обмінні пункти та інші корисні секретні містечка. } \\
\text { Уточнити реальні ціни на місцевий сервіс і отримати відповіді на } \\
\text { всі свої питання про м. Приморськ. Це допоможе зорієнтуватися } \\
\text { на місці, самим будувати свій відпочинок і, звичайно, заощадити. }\end{array}$ \\
\hline $\begin{array}{c}\text { Відкриття } \\
\text { заливу }\end{array}$ & щоденно & $\begin{array}{l}\text { Екскурсія вглиб Обіточного заливу. Знайомство з чудовою } \\
\text { природою, панорамні види, занурення, відкриття загубленої } \\
\text { лагуни, купання в ній. Екскурсія на весь день. }\end{array}$ \\
\hline Круїз-рибалка & щоденно & $\begin{array}{l}\text { Вихід в море на комфортабельній яхті з каютами. Дворазове } \\
\text { харчування: обід і вечеря в морі. Пірнання з інструкторами. } \\
\text { Рибалка. Зустріч заходу сонця в морі. Круїз на весь день. }\end{array}$ \\
\hline $\begin{array}{c}\text { Фантастичний } \\
\text { круїз }\end{array}$ & щоденно & $\begin{array}{l}\text { Розважальний круїз для сімей з дітьми. Тривалість } 3 \text { години. } \\
\text { За цей час аніматори розважатимуть дітей, фрокусники } \\
\text { зачаровуватимуть, а море надихатиме на повний відпочинок. }\end{array}$ \\
\hline Морські каяки & щоденно & Вихід на каяках на світанку. Зустріч перших сонячних променів. \\
\hline
\end{tabular}


для творчості тут досить широке і охоплює не тільки одяг: можна розписати шкіру хною або аквагримом, пофрантазувати 3 головними уборами чи зачісками.

- Особливий стиль спілкування 3 гостями на тематичних урочистостях: можна використовувати кодові фррази, вітати гостей на мові країни, кухня якої представлена на заході, а також включати спеціальні жести або ритуали.

- Заходи з мотивів блокбастерів, де учасникам пропонують відчути себе героями кінострічки, виявилися на піку популярності ще рік тому. Однак такі розваги швидко втрачають актуальність, адже фрільми забуваються.

Переваги організації служби кейтерингу при готелі [10]:

- повністю задовільнить будь-яку потребу в сорері організації харчування на судні - від простого обіду на 1 людину до повноцінного класичного кейтерингу на кілька сотен осіб;

- смакова палітра створена на основі фрілососрії здорового харчування. Особливістю кейтерингу при готелі буде можливість реалізовувати тематичне меню за індивідуальним запитом;

- організація тематичних анімаційних станцій, коли команда кухарів готує прямо при гостях, роблячи захід більш запам'ятовуючим і статусним;

- в арсеналі кейтерингової служби має бути все, що потрібно для створення заходів будь-якого формату:

- власний лофт-майданчик та намети різної місткості, біля готелю;

- транспорт, меблі, посуд в асортименті, текстиль;

- максимально укомплектований персонал - від прибиральників до фрахівців по сервіровці;
- фрахівці всіх напрямків event-послуг - провідні, діджеї, аніматори, декоратори, фотографи, організатори весіль та інших подій.

- організація виїзних заходів: виставки, дні народження і весілля на обраних клієнтами майданчиках.

- організація кейтерингу на суднах.

- під час VIP екскурсій з обслуговуванням можна обирати не тільки готові позиції 3 меню, а й обговорити з менеджером можливість створення персоналізованих страв - в кольорах бренду або з додаванням інгредієнтів, які використовує компанія.

Висновки. Отже, туризм в м. Приморськ може бути представлений подорожами по морських хвилях. Обрано морський транспорт призначений як для здійснення екскурсійних морських прогулянок околицями, так і для тривалих плавань в Батумі, Стамбул. Клас судів гарантує безпеку і високий рівень комсрорту кожного подорожуючого.

Організація кейтерингового обслуговування під час морських екскурсій має забезпечити високий рівень харчування і задоволення споживачів. Для досягнення цієї мети потрібно передбачити устаткування, яке відповідатиме вимогам мобільності, забезпечуватиме високі споживчі показники продукції ресторанного господарства, для оригінальної подачі страви передбачити використання нестандартного посуду, гостей також пропонується залучати в процес створення страв.

Активний відпочинок на морі в м. Приморськ набагато цікавіше, ніж простий традиційна відпустка на пляжі. Це абсолютно нові відчуття і емоції, цікавий погляд на звичні пейзажі узбережжя, прекрасний спосіб згуртувати команду друзів, колег або членів сім'ї.

\section{СПИСОК ВИКОРИСТАНИХ ДЖЕРЕЛ:}

1. Только треть украинцев отдыхает за границей - исследование. URL: https://www.epravda.com.ua/ news/2019/06/11/648650/ (дата звернення: 14.12.2020).

2. Наврозова Ю.А., Михайлова Ю.В. Сущность и виды морского туризма. Розвиток методів управління та господарювання на транспорті : зб. наук. праць. Одеса, 2013. Вип. (4) 41. С. 45-54.

3. Кирпіченкова О.М. Сучасні методи забезпечення сталого розвитку готельного господарства. Сталий розвиток погляд молоді : матеріали I міжнародної науково-практичної конференції для студентів і молодих вчених (Київ, 28 лютого 2020 року) / за заг. ред. проф. О.О. Романовського, Л.В. Жарової, Т.В. Мірзодаєвої. Київ : Українсько-американський університет Конкордія, 2020. С. 19-21.

4. Поминчук І.Ю., Кирпіченкова О.М. Розширення спектру додаткових послуг у готелях. «Інноваційні технології в готельно-ресторанному бізнесі» : матеріали VIII Всеукраїнської науково-практичної консреренції, присвяченої 135-річчю Національного університету харчових технологій (Київ, 19-20 березня 2019 р.). Київ : HУXT, 2019. С. 53.

5. Шидловська О.Б., Іщенко Т.І., Медвідь І.М., Шевела Я.С. Інноваційні напрямки розвитку агротуризму в Україні. Географрія та туризм. Київ : Альфра-ПІК, 2016. Вип. 35. С. 61-70. 
6. Сулик М.О., Шаран Л.О. Інноваційний продукт закладів готельного господарства. Проблеми фрормування здорового способу життя у молоді : матеріали X Всеукр. наук.-практ. конфр. молодих учених та студентів. Одеса : ОНАХТ, 2016. С. 188-189.

7. Абрамова А.Г., Хоменко А.А., Савега О.Є. Теоретичні аспекти розширення анімаційних послуг для підприємств готельного господарства. SWorld Journal: International periodic scientific journal. SWorld \& D.A. Tsenov Academy of Economics. Svishtov, Bulgaria, 2019. № 1. C. 141-146.

8. Смирнов І.Г. Логістика кейтерингу. Географрія та туризм. 2014. Вип. 28. С. 42-50.

9. Голубкова И.А. Экономический механизм развития круизного судоходства Украины : монограсрия. Одесса : ИздатИнформ, 2011. С. 123-127.

10. Меттел, Б. Кейтеринг. Руководство по эфффективному управлению бизнесом. Кулинарный институт Америки. Москва : "BBPG", 2012. 368 с.

\section{REFERENCES:}

1. Only a third of Ukrainians rest abroad - a study. Retrieved from: https://www.jakda.com.ua/news/2019/ $06 / 11 / 648650 /$

2. Navrozova Y.A. (2013). The essence and types of sea tourism. Development of management methods and management in transport: collection. science. works, Odessa, (4) 41, 45-54.

3. Kyrpichenkova O.M. (2020). Suchasni metody zabezpechennia staloho rozvytku hotelnoho hospodarstva. Stalyi rozvytok pohliad molodi: materialy I mizhnarodnoi naukovopraktychnoi konferentsii dlia studentiv i molodykh vchenykh (Kyiv, 28 liutoho 2020 roku) / za zah. red. prof. O.O. Romanovskoho, L.V. Zharovoi, T.V. Mirzodaievoi. Kyiv: Ukrainsko-amerykanskyi universytet Konkordiia.

4. Pomynchuk I.Yu., Kyrpichenkova O.M. (2019). Rozshyrennia spektru dodatkovykh posluh u hoteliakh. «Innovatsiini tekhnolohii v hotelno-restorannomu biznesi»: materialy VIII Vseukrainskoi naukovo-praktychnoi konferentsii, prysviachenoi 135-richchiu Natsionalnoho universytetu kharchovykh tekhnolohii (Kyiv, 19-20 bereznia 2019 r.). Kyiv: NUKhT.

5. Shydlovska O.B., Ishchenko T.I., Medvid I.M., Shevela Ya.S. (2016). Innovatsiini napriamky rozvytku ahroturyzmu v Ukraini. Heohrafiia ta turyzm. Kyiv: Alfa-PIK, vol. 35, pp. 61-70.

6. Sulyk M.O., Sharan L.O. (2016). Innovatsiinyi produkt zakladiv hotelnoho hospodarstva. Problemy formuvannia zdorovoho sposobu zhyttia u molodi: materialy $X$ Vseukr. nauk.-prakt. konf. molodykh uchenykh ta studentiv. Odesa: ONAKhT.

7. Abramova A.H., Khomenko A.A., Saveha O.Ye. (2019). Teoretychni aspekty rozshyrennia animatsiinykh posluh dlia pidpryiemstv hotelnoho hospodarstva. SWorld Journal: International periodic scientific journal. SWorld \& D.A. Tsenov Academy of Economics. Svishtov, Bulgaria, 1, 141-146.

8. Smirnov I.G. (2014). Catering logistics. Geography and Tourism, 28, 42-50.

9. Golubkova I.A. (2011). Economic mechanism of cruise shipping development of Ukraine: monograph. Odessa: IzdatInform. (in Ukrainian)

10. Mettel B. (2012). Catering. A guide to effective business management. Culinary Institute of America. Moscow: "BBPG". (in Russian) 